\title{
PENGENALAN BUAH KOPI BERDASARKAN PARAMETER WARNA MENGGUNAKAN ALGORITMA BACKPROPAGATION DAN ALGORITMA SUPPORT VECTOR MACHINE (SVM)
}

\section{INTRODUCTION OF COFFEE FRUIT BASED ON COLOR PARAMETER USING BACKPROPAGATION ALGORITHM AND SUPPORT VECTOR MACHINE (SVM) ALGORITHM}

\author{
Inte Christinawati Buulolo ${ }^{1}$, Helda Agave Sihombing ${ }^{2 *}$ \\ ${ }^{1,2}$ Institut Teknologi Del, Jl.P.I.Del,Sitoluama, Laguboti, Kabupaten Toba, Sumatera Utara
}

*E-mail: heldaagavesihombing@gmail.com

\begin{abstract}
ABSTRAK
Salah satu kopi arabika unggulan Indonesia adalah Kopi Lintong yang berasal dari Sumatera Utara. Peneliti akan melakukan 2 percobaan yaitu percobaan I untuk memperoleh model terbaik dalam melakukan klasifikasi buah kopi arabika varietas Sigarar Utang. Sedangkan percobaan II dilakukan untuk mengetahui objek mana yang lebih baik digunakan dalam klasifikasi kopi berkualitas berdasarkan fitur warna, apakah buah kopi atau biji kopi. Dataset yang digunakan pada percobaan I adalah berupa 250 gambar buah kopi kualitas baik dan 250 gambar buah kopi kualitas kurang yang diambil langsung dari KSU POM Humbang Cooperative. Kemudian dilakukan image preprocessing yang menghasilkan 2500 gambar baru. Sedangkan dataset yang digunakan pada percobaan II adalah data buah kopi dan biji kopi. Buah kopi terdiri dari 240 gambar buah kopi baik dan 240 gambar buah kopi cacat hasil image rotation. Biji kopi terdiri dari 240 gambar biji kopi baik dan 240 gambar biji kopi cacat. Data tersebut kemudian akan dilakukan ekstraksi fitur dengan menggunakan metode HSV (Hue, Saturation, Value). Selanjutnya akan dilakukan proses learning menggunakan algoritma Backpropagation dan algoritma Support Vector Machine (SVM) dengan tiga jenis kernel yaitu RBF, polynomial, dan sigmoid. Berdasarkan pengujian yang telah dilakukan, maka diperoleh hasil pada percobaan I menghasilkan model klasifikasi terbaik dengan menggunakan algoritma SVM dengan kernel RBF menghasilkan nilai akurasi sebesar $86 \%$ dan nilai f-score sebesar $86 \%$. Untuk percobaan II memperoleh hasil bahwa buah kopi dan biji kopi baik digunakan sebagai objek dalam pengenalan buah kopi berdasarkan fitur warna dengan menggunakan machine learning.
\end{abstract}

Kata kunci: machine learning, image preprocessing, fitur warna, algoritma Backpropagation, algoritma Support Vector Machine.

\begin{abstract}
One of Indonesia's leading Arabica coffees is Lintong Coffee originating from North Sumatra. Researchers will conduct 2 experiments, namely Experiment I to obtain the best model in classifying Arabica coffee cherries of the Sigarar Utang variety. While Experiment II was conducted to find out which object is better used in the classification of quality coffee based on color parameters, whether coffee cherries or coffee beans. The dataset used in the first experiment was 250 images of good quality coffee cherries and 250 images of poor quality coffee cherries taken directly from KSU POM Humbang Cooperative. Then do image preprocessing which produces 2500 new images. While the dataset used in experiment II is data on coffee cherries and coffee beans. Coffee cherries consist of 240 images of good coffee cherries and 240 images of defective coffee cherries resulting from image rotation. Coffee beans consist of 240 pictures of good coffee beans and 240 pictures of defective coffee beans. The data will then be extracted using the HSV (Hue, Saturation, Value) method. Furthermore, the learning process will be carried out using the Backpropagation algorithm and the Support Vector Machine (SVM) algorithm with three types of kernels, namely RBF, polynomial, and sigmoid. Based on the tests that have been carried out, the results obtained in the first experiment resulted in the best classification model with the SVM algorithm with the RBF kernel producing an accuracy value of $86 \%$ and anf-score value of $86 \%$. For the second experiment, the results showed that coffee cherries and coffee beans were used as objects in the recognition of coffee cherries based on color features using machine learning.
\end{abstract}

Keywords: machine learning, image preprocessing, color feature, Backpropagation, Support Vector Machine. 


\section{PENDAHULUAN}

Secara umum kopi dikenal dengan 2 spesies yaitu kopi robusta dan kopi arabika. Salah satu kopi arabika unggulan Indonesia adalah Kopi Lintong yang berasal dari Sumatera Utara. Kopi Lintong terkenal dikalangan pecinta kopi dalam negeri maupun luar negeri dikarenakan keharuman dan citarasa yang khas. Kopi lintong memiliki tekstur halus dan aroma yang khas. Kopi lintong merupakan merek dagang yang diambil dari nama tempat yaitu Lintong Nihuta.

Penelitian yang akan dilakukan merupakan lanjutan dari penelitian mengenai pengenalan buah kopi berkualitas yang telah dilakukan sebelumnya oleh Indriani Tiosari Sitorus dan Debora Rodearna Simarmata dengan judul Pengenalan Buah Kopi Arabika varietas Sigarar Utang Berdasarkan Parameter Tekstur Menggunakan Machine Learning (Studi Kasus : KSU POM Humbang Cooperative) pada tahun 2020[1]. Penelitian tersebut berfokus pada membedakan antara biji kopi cacat dan tidak cacat pada green bean kopi dengan menggunakan metode Machine Learning dengan parameter tekstur melalui citra buah kopi. Dimana fitur tekstur digunakan sebagai fitur yang dapat mengklasifikasikan buah kopi cacat dan buah kopi tidak cacat menggunakan pendekatan Machine Learning. Hasil dari penelitian tersebut yaitu kombinasi algoritma Support Vector Machine (SVM) dengan kernel terbaik. Pemodelan terbaik tersebut diperoleh dengan cara membandingkan hasil pengenalan algoritma SVM dengan kernel terbaik terhadap buah kopi cacat dan tidak cacat berdasarkan parameter tekstur.

Penelitian Indriani dan Debora [1] menyarankan peneliti selanjutnya menggunakan parameter warna untuk dapat membandingkan hasil penelitian tersebut dengan penelitian yang akan dilakukan. Oleh karena itu, penelitian ini akan melakukan pengenalan buah kopi arabika varietas sigarar utang dengan menggunakan parameter warna. Pada penelitian sebelumnya objek penelitian yang digunakan yaitu green bean coffee. Pada penelitian objek yang akan diteliti adalah buah kopi (cherry coffee) dan biji kopi (green bean coffee). Pada tahap percobaan, penulis akan menjalankan eksperimen untuk mengenali kualitas biji kopi (green bean coffee) dan buah kopi (cherry coffee), kemudian hasilnya dibandingkan. Hal tersebut dilakukan untuk mengetahui objek mana yang lebih baik digunakan dalam klasifikasi kopi berkualitas berdasarkan parameter warna, apakah buah kopi atau biji kopi.

Peneliti melihat bahwa penelitian yang dilakukan sebelumnya dengan metode SVM telah baik yang dapat dilihat dari tingkat akurasi algoritma dalam melakukan pengenalan buah kopi, untuk itu peneliti akan tetap melanjutkan menggunakan metode SVM. Algoritma SVM akan dibandingkan dengan algoritma Backpropagation. Algoritma Backpropagation dipilih karena algoritma Backpropagation mempunyai cara kerja dengan menyesuaikan bobot yang saling terhubung antara neuron untuk mencapai kesalahan minimum antara keluaran hasil prediksi dengan keluaran yang nyata [6]. Selain itu jaringan syaraf tiruan backpropagation memiliki kelebihan lain dibandingkan jaringan syaraf tiruan lainnya yaitu jaringan syaraf tiruan backpropagation menggunakan pelatihan terawasi. Pada penelitian yang telah dilakukan sebelumnya oleh Ria Angellina [2] mengenai perbandingan metode Backpropagation dan SVM dalam klasifikasi emosi pada pesan teks menghasilkan bahwa algoritma SVM memiliki performa yang lebih baik jika dibandingkan dengan algoritma backpropagation yaitu dengan akurasi $81 \%$ sedangkan algoritma backpropagation menghasilkan nilai akurasi sebesar 53\%. Pada penelitian ini kedua algoritma dibandingkan dengan menggunakan ojek yang berbeda dengan objek yang digunakan pada penelitian sebelumnya dengan tujuan untuk mengetahui performa dari algoritma SVM dan backpropagation dalam melakukan klasifikasi buah kopi.

Pada penelitian sebelumnya yang dilakukan oleh Indriani dan Debora [1] metode SVM dilakukan menggunakan kombinasi algoritma SVM dengan tiga jenis kernel yang berbeda yaitu RBF, polynomial, dan sigmoid untuk menghasilkan pemodelan yang terbaik dan telah mendapatkan hasil pemodelan terbaik yaitu dengan menggunakan jenis kernel polynomial dengan akurasi terbaik yaitu sebesar 96\%. Pada penelitian ini juga akan menggunakan ketiga jenis kernel tersebut karena objek yang diteliti berbeda dari penelitian yang telah dilakukan sebelumnya. Pada penelitian sebelumnya hanya menggunakan biji kopi sebagai objek, sedangkan pada penelitian Tugas Akhir ini akan menggunakan buah kopi dan biji kopi sebagai objek penelitian. Hanya saja penelitian ini akan fokus untuk memproses data buah kopi dari awal, sementara data biji kopi diperoleh dari 
sumber lain yaitu data dari penelitian TA2020/2021-9A oleh Amelia Septiani Manurung [3].

\section{METODOLOGI}

Pada penelitian ini sumber data yang digunakan ada dua yaitu data buah kopi yang diperoleh langsung dari KSU POM Humbang Cooperative. Data yang kedua adalah data biji kopi yang diperoleh dari dataset kelompok TA2020/2021-9A IT Del [3]. Kemudian akan dilakukan image preprocessing dan ektraksi fitur.

\section{Pengumpulan Data}

Pada penelitian ini sumber data yang digunakan ada dua yaitu data buah kopi yang diperoleh langsung dari KSU POM Humbang Cooperative. Data yang kedua adalah data biji kopi yang diperoleh dari dataset kelompok TA2020/2021-9A IT Del [3].

Adapun data yang digunakan yaitu 250 gambar buah kopi yang baik (grade 1) dan 250 gambar buah kopi dengan kualitas kurang (grade 2). Dengan demikian total data yang dikumpulkan oleh peneliti dari KSU POM Humbang Cooperative adalah sebanyak 500 gambar buah kopi. Sedangkan data yang kedua yaitu biji kopi (green bean coffee) menggunakan 240 gambar buah kopi baik dan 240 gambar buah kopi cacat. Masing-masing gambar hanya berisi satu buah kopi atau satu biji kopi.

\section{Image Preprocessing}

Image preprocessing merupakan sebuah proses yang dilakukan untuk memperhalus suatu gambar dalam hal karakter digital, yang berfungsi untuk meningkatkan kualitas sebuah gambar. Tujuan dilakukannya preprocessing yaitu untuk mengubah intensitas pixel gambar agar mudah digunakan pada proses selanjutnya. Adapaun metode image preprocessing yang diterapkan pada penelitian ini adalah resize dan augmentasi. Tujuan dilakukannya resize adalah untuk menyamakan ukuran dari gambar sedangkan augmentasi dilakukan untuk memperbanyak jumlah data. Metode augmentasi yang dilakukan yaitu dengan cropping dan image rotation. Jumlah data yang dihasilkan setelah dilakukannya image preprocessing adalah sebanyak 2500 gambar.

\section{Feature Extraction}

Feature extraction adalah proses mengenali ciri-ciri yang terdapat pada sebuah gambar. Tujuan dari feature extraction adalah untuk mengetahui/mengenali suatu gambar dari karakteristik yang ada pada gambar. Ekstraksi fitur dilakukan untuk mendapatkan nilai fitur suatu objek berdasarkan hubungan nilai intensitas piksel suatu citra. Pada penelitian ini ektraksi fitur yang digunakan yaitu berdasarkan fitur warna dengan model warna HSV. Ektraksi fitur akan dilakukan terhadap 2500 gambar hasil preprocessing.

Pemodelan warna HSV memiliki kelebihan yaitu sangat mirip dengan model warna RGB (Red, Green, Blue) sehingga mirip dengan warna aslinya. Akan tetapi, HSV memiliki komponen yang lebih kompleks dari RGB sehingga warna yang dihasilkan semakin menyerupai aslinya.

Setiap komponen warna memiliki tiga karakteristik utama yaitu [5]:

a) Hue yaitu digunakan untuk membedakan warna dan menentukan kemerahan, kehijauan dan lain sebagainya dari cahaya. Hue menyatakan warna yang sebenarnya.

b) Saturation untuk menyatakan tingkat kemurnian/kedalaman pada hue.

c) Value merupakan kecerahan dari suatu warna (banyaknya cahaya yang diterima oleh mata).

4. Implementasi

Langkah selanjutnya adalah melakukan implementasi. Pada penelitian ini akan melakukan 2 percobaan yaitu:

a. Pada percobaan I akan dilakukan klasifikasi buah kopi (cherry coffee) dengan menggunakan metode SVM dan Backpropagation yang bertujuan untuk memperoleh model terbaik dalam melakukan pengenalan buah kopi kualitas baik dan kualitas kurang dengan menggunakan fitur warna.

b. Pada percobaan II akan dilakukan klasifikasi biji kopi (green bean) dan buah kopi (cherry coffee). Percobaan ini dilakukan dengan tujuan untuk mengetahui objek yang lebih baik digunakan dalam pengenalan kopi berkualitas dengan menggunakan fitur warna.

Kedua percobaan tersebut akan dilakukan dengan menggunakan algoritma algoritma Backpropagation dan Support Vector Machine.

4.1 Backpropagation 
Backpropagation Neural Network (BPNN) merupakan sebuah algoritma yang digunakan pada Artificial Neural Network (ANN) dengan pembelajaran terawasi yang akan menyesuaikan bobot secara berulang yang bertujuan untuk mendapat nilai error terkecil antara target dengan hasil prediksi yang diperoleh. Backpropagation merupakan bagian dari algoritma jaringan syaraf tiruan dengan kernel yang digunakan berupa sigmoid biner. Backpropagation memiliki 3 tahapan, yaitu: feedforward pola training data, backpropagation terhadap error, serta penyesuaian bobot. BPNN terdiri dari 3 layer yaitu hidden layer, input layer dan output layer.

4.2 Support Vector Machine (SVM)

Support Vector Machine (SVM) pertama kali dikenalkan oleh Vapnik tahun 1992 sebagai salah satu metode machine learning yang bekerja dengan prinsip Structural Risk Minimization (SRM) yang bertujuan untuk menemukan hyperplane terbaik yang memisahkan dua buah class pada input space [4]. Hyperplane adalah garis yang digunakan untuk memisahkan dataset. Keuntungan dari metode SVM adalah dapat meningkatkan kinerja pada generalisasi dengan pemilihan penggunaan fungsi kernel yang tepat. Fungsi kernel merupakan suatu fungsi yang memetakan data ke ruang dimensi yang lebih tinggi dengan harapan data akan memiliki struktur yang lebih baik sehingga lebih mudah dipisahkan.

\section{HASIL DAN PEMBAHASAN}

Pada bagian ini dijelaskan mengenai hasil dan pembahasan dari implementasi yang telah dilakukan pada penelitian ini. Hasil yang telah diperoleh dari tahap implementasi dan juga pembahasan dari hasil yang didapatkan.

1. Percobaan I

Pada bagian ini akan diuraikan hasil yang diperoleh dari percobaan 1 .

\subsection{Percobaan dengan menggunakan algoritma} Backpropagation

Pada bagian ini akan diuraikan hasil dari klasifikasi buah kopi berdasarkan fitur warna menggunakan algoritma Backpropagation dengan skema pembagian dataset yaitu 90\%:10\%, 80\%:20\%, 70\%:30\%, 60\%:40\%, 50\%:50\%, 40\%:60\%, 30\%:70\%, 20\%:80\%, dan 10\%:90\%. Perbandingan nilai accuracy dan nilai $f$-score terbaik dari masingmasing pemodelan yang ada pada skema pembagian dataset dapat dilihat pada Gambar 1 .

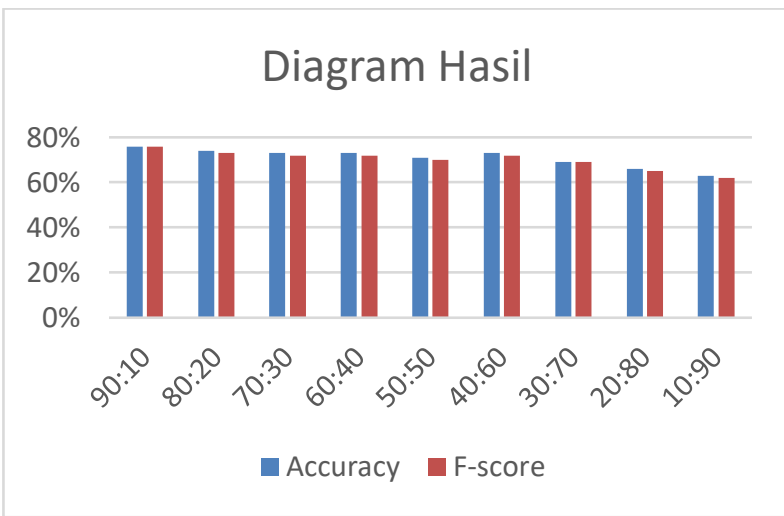

Gambar 1. Perbandingan Hasil pada Algoritma Backpropagation

Berdasarkan diagram diatas dapat dilihat 1 bahwa algoritma Backpropagation melakukan klasifikasi buah kopi dengan nilai accuracy dan nilai $f$-score tertinggi yaitu pada pembagian dataset 90:10 dengan nilai accuracy sebesar $76 \%$ dan nilai $f$-score sebesar $76 \%$.

\subsection{Percobaan dengan menggunakan algoritma}

\section{Support Vector Machine}

Bagian ini akan menjelaskan mengenai hasil pengujian SVM dengan tiga jenis kernel yaitu kernel RBF, polynomial, dan sigmoid yang menampilkan masing-masing model kernel pada setiap skema pembagian dataset. skema pembagian datasetyang digunakan yaitu 90\%:10\%, 80\%:20\%, 70\%:30\%, 60\%:40\%, 50\%:50\%, 40\%:60\%, 30\%:70\%, 20\%:80\%, dan 10\%:90\%. Perbandingan nilai accuracy dan $f$ score algoritma SVM pada masing-masing perbandingan dataset dapat dilihat pada Gambar 2.

Berdasarkan diagram pada Gambar 2 dapat dilihat bahwa pada model rbf nilai accuracy dan f-score tertinggi adalah $86 \%$ dan $85 \%$ pada skema pembagian dataset 90:10. Pada model polynomial nilai accuracy dan $f$-score tertinggi adalah $78 \%$ pada skema pembagian dataset 80:20. Pada model sigmoid nilai accuracy dan $f$-score tertinggi adalah $44 \%$ dan $43 \%$ pada skema pembagian data 10:90. Berdasarkan data tersebut dapat disimpulkan bahwa kernel rbf menghasilkan nilai accuracy dan $f$-score yang tertinggi dalam melakukan klasifikasi buah kopi, yaitu pada skema pembagian dataset 
90:10 dengan nilai accuracy sebesar $86 \%$ dan nilai $f$-score sebesar $85 \%$.

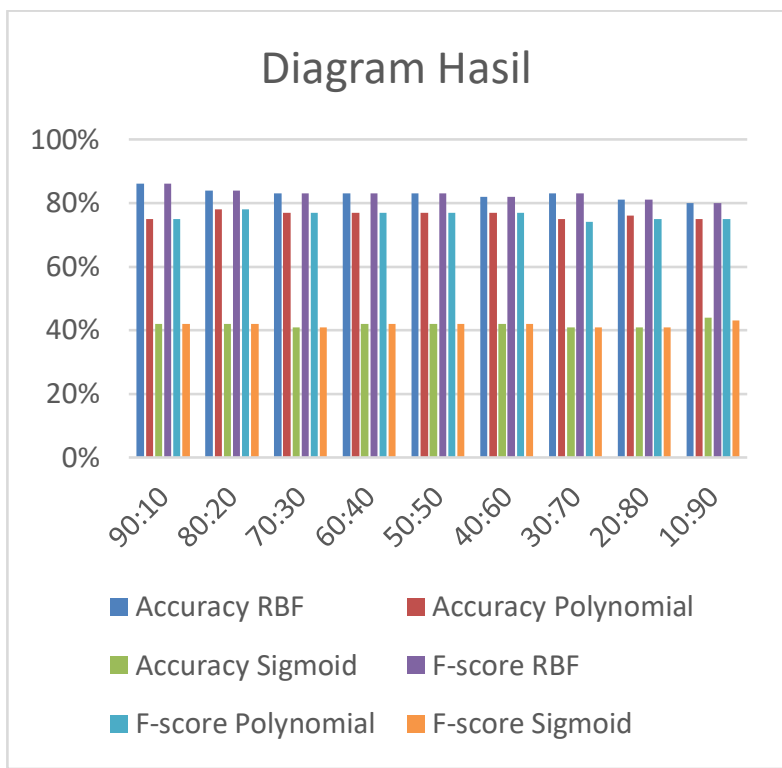

Gambar 2. Perbandingan Hasil pada Algoritma Support vector Machine

\subsection{Hasil Percobaan I}

Bagian ini akan dibahas mengenai hasil klasifikasi dari kedua algoritma yang digunakan dalam penelitian Tugas Akhir yaitu algoritma SVM dengan mengimplementasikan 3 kernel dan algoritma Backpropagation. Perbandingan accuracy dan $f$-score terbaik algoritma SVM dan backpropagation dapat dilihat pada Gambar 3.

Berdasarkan diagram pada Gambar 3 dapat dilihat bahwa algoritma SVM memiliki nilai accuracy dan nilai $f$-score yang lebih tinggi dibandingkan dengan algoritma Backpropagation. Algoritma SVM memiliki nilai accuracy dan $f$-score tertinggi pada pembagian dataset 90:10 dengan nilai accuracy $86 \%$ nilai $f$-score sebesar $85 \%$, sedangkan algoritma backpropagation memiliki nilai akurasi tertinggi pada pembagian dataset 90:10 dengan nilai accuracy sebesar nilai $f$-score sebesar $76 \%$.

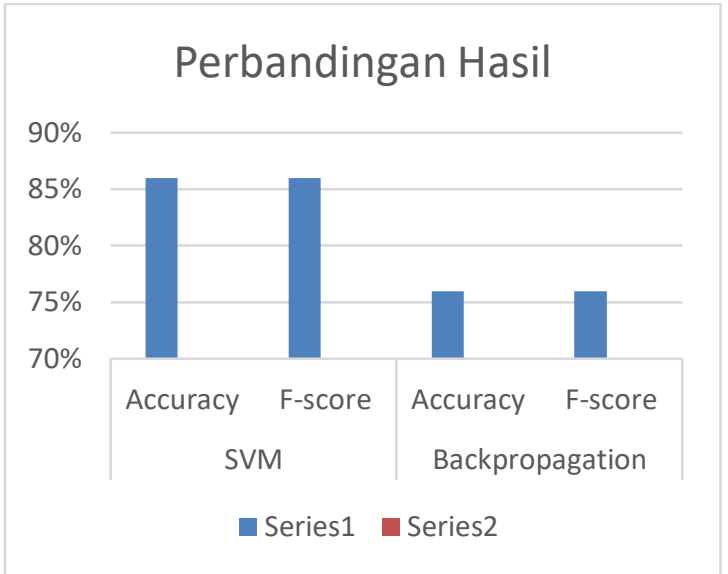

Gambar 3. Perbandingan Hasil Percobaan I

\section{Percobaan II}

Pada bagian ini akan diuraikan hasil yang diperoleh dari percobaan II.

\subsection{Percobaan dengan Green Bean Coffee}

Bagian ini akan dijelaskan mengenai hasil dan pembahasan yang didapat dengan melakukan percobaan pada green bean coffee dengan menggunakan algoritma SVM dan Backpropagation pada dataset 90:10. Hasil percobaan dengan green bean coffee menggunakan algoritma SVM dapat dilihat pada Tabel 1.

Tabel 1. Hasil Percobaan Green Bean Coffee dengan SVM

\begin{tabular}{ccc}
\hline Pembagian dataset & Akurasi & F-score \\
\hline $90: 10$ & $100 \%$ & $100 \%$
\end{tabular}

Berdasarkan tabel di atas dapat dilihat bahwa percobaan dengan menggunakan data green bean coffee menggunakan algoritma SVM menghasilkan nilai akurasi sebesar $100 \%$ dan nilai $f$-score sebesar $100 \%$.

Hasil percobaan dengan green bean coffee menggunakan algoritma backpropagation dapat dilihat pada Tabel 2 .

Tabel 2. Hasil Percobaan Green Bean Coffee dengan Backpropagation

\begin{tabular}{ccc}
\hline Pembagian dataset & Akurasi & F-score \\
\hline $90: 10$ & $46 \%$ & $31 \%$ \\
\hline
\end{tabular}

Berdasarkan tabel di atas dapat dilihat bahwa percobaan dengan menggunakan data green bean coffee menggunakan algoritma 
backpropagation menghasilkan nilai akurasi sebesar $46 \%$ dan nilai $f$-score sebesar $31 \%$.

\subsection{Percobaan dengan Cherry Coffee}

Bagian ini akan dijelaskan mengenai hasil dan pembahasan yang didapat dengan melakukan percobaan pada green bean coffee dengan menggunakan algoritma svm dan backpropagation pada dataset 90:10. Hasil percobaan dengan cherry coffee menggunakan algoritma SVM dapat dilihat pada Tabel 3.

Tabel 3. Hasil Percobaan dengan Cherry Coffee Menggunakan Algoritma SVM

\begin{tabular}{ccc}
\multicolumn{3}{c}{ Menggunakan Algoritma SVM } \\
\hline Pembagian dataset & Akurasi & F-score \\
\hline $90: 10$ & $100 \%$ & $100 \%$ \\
\hline
\end{tabular}

Berdasarkan tabel di atas dapat dilihat bahwa percobaan dengan menggunakan data cherry coffee menggunakan algoritma SVM menghasilkan nilai akurasi sebesar $100 \%$ dan nilai $f$-score sebesar $100 \%$.

Hasil percobaan dengan cherry coffee menggunakan algoritma backpropagation dapat dilihat pada Tabel 4.

Tabel 4. Hasil Percobaan dengan Cherry Coffee Menggunakan Algoritma Backpropagation

\begin{tabular}{ccc}
\hline Pembagian dataset & Akurasi & F-score \\
\hline $90: 10$ & $45 \%$ & $31 \%$
\end{tabular}

Berdasarkan tabel 4 di atas dapat dilihat bahwa percobaan dengan menggunakan data cherry coffee menggunakan algoritma backpropagation menghasilkan nilai akurasi sebesar $47 \%$ dan nilai $f$-score sebesar $31 \%$.

\subsection{Hasil Percobaan II}

Dari hasil yang telah diperolah pada percobaan II dapat disimpulkan bahwa green bean coffee dapat diklasifikasikan dengan baik oleh algoritma machine learning. Objek buah kopi dan biji kopi sama-sama baik digunakan untuk melakukan pengenalan kopi berkualitas dikarenakan nilai akurasi dan $f$-score yang dihasilkan pada percobaan ke II tidak jauh berbeda.

\section{KESIMPULAN}

Berdasarkan hasil yang telah diperoleh selama proses pengerjaan, dapat disimpulkan bahwa pada percobaan I model klasifikasi terbaik dalam melakukan klasifikasi buah kopi arabika varietas Sigarar Utang adalah algoritma Support Vector Machine menggunakan kernel
RBF dengan nilai akurasi sebesai $86 \%$ dan nilai $f$-score sebesar $86 \%$ seperti hasil yang diperoleh pada percobaan I. Hal tersebut dikarenakan algoritma SVM baik dalam melakukan klasifikasi terhadap data nonlinier seperti data yang digunakan pada penelitian ini, dengan memetakan ke dimensi yang lebih tinggi menggunakan fungsi kernel. Sedangkan pada percobaan ke II dapat disimpulkan bahwa Objek buah kopi dan biji kopi sama-sama baik digunakan untuk melakukan pengenalan kopi berkualitas dikarenakan nilai akurasi dan $f$ score yang dihasilkan pada percobaan I sudah baik, dan juga nilai akurasi dan $f$-score yang dihasilkan pada percobaan ke II tidak jauh berbeda.

\section{SARAN}

Berdasarkan hasil analisis dan kesimpulan, berikut adalah saran untuk dapat dikembangkan pada penelitian selanjutnya. Pada penelitian selanjutnya sebaiknya menggabungkan kombinasi ektraksi fitur warna, fitur bentuk dan fitur tekstur dari buah kopi dan menguji fitur-fitur tersebut secara bersamaan. Peneliti juga menyarankan untuk penelitian yang akan dilakukan selanjutnya untuk meneliti gambar yang berisi banyak buah kopi bukan hanya satu buah kopi.

\section{UCAPAN TERIMA KASIH}

Penulis mengucapkan terima kasih kepada Lembaga Penelitian dan Pengabdian kepada Masyarakat (LPPM) Institut Teknologi Del yang telah mendukung pendanaan publikasi ini.

\section{DAFTAR PUSTAKA}

[1] Simarmata, I. T. (2020). Pengenalan Biji Kopi Arabika Varietas Sigarar Utang Berdasarkan Parameter Tekstur Menggunakan Machine Learning (Studi Kasus : KSU POM Humbang Cooperative). Pengenalan Biji Kopi Arabika varietas Sigarar Utang Lintong, 5-6.

[2] Angellina, R. (202). Perbandingan Metode Backpropagation Dan Support Vector Machine Dalam Klasifikasi Emosi Pada Pesan Teks.

[3] Manurung, A. S. (2021). Perbandingan Ekstraksi Bentuk dengan Ekstraksi Tekstur 
menggunakan Algoritma SVM (Support Vector Machine) dalam Menentukan Kualitas Biji Kopi Arabika varietas Sigarar Utang.

[4] Feldman, R., \& Sanger, J., (2007) The Text Mining Handbook, Advanced Approaches in Analyzing Unstructured Data.

[5] Junhua, C. \& Jing, L., 2012. Research on Color Image Classification Based on HSV Color Space. Second International Conference on Instrumentation \& Measurement, Computer, Communication and Control.

[6] Lee, S., \& Choi, W. S. (2013). A MultiIndustry Bankruptcy Prediction Model using Back-Propagation Neural Network and Multivariate Discriminant Analysis. Expert Systems with Applications, 40(8): 2941-2946. 